\title{
Clinicopathological and prognostic significance of the microRNA processing enzyme DICER1 mRNA expression in colorectal cancer patients
}

\author{
TAKUYA AKAHANE \\ Department of Surgery, Teikyo University School of Medicine, Tokyo 173-0003, Japan
}

Received September 4, 2012; Accepted October 29, 2012

DOI: $10.3892 / \mathrm{mco} .2012 .43$

\begin{abstract}
The cytoplasmic ribonuclease DICER1 is one of the key enzymes in microRNA (miRNA) processing, essential for the production of mature miRNA. The effect of DICER 1 expression in tumor cells on the prognosis of patients with several cancers has been examined with controversial results in various cancer types. In particular, the clinical significance of DICER1 expression in colorectal cancer (CRC) patients has yet to be determined. The aim of this study was to evaluate the correlation between the DICER1 mRNA levels and the clinicopathological characteristics and prognostic significance in CRC patients. Tumor and normal adjacent tumor tissues from 260 patients with CRC (Dukes' stage A: 40 cases, Dukes' B: 68 cases, Dukes' C: 88 cases and Dukes' D: 64 cases) were examined. The DICER1 mRNA levels were measured using the TaqMan real-time reverse transcription polymerase chain reaction (RT-PCR) method. The expression levels of DICER1 mRNAs showed a significant decrease in CRC tissues as compared to normal ones $(\mathrm{P}=0.039)$. A statistically significant association was observed between DICER1 mRNA expression and tumor size, depth of invasion, lymph node metastasis, lymphatic invasion and Dukes' stage. In Kaplan-Meier survival curve analysis, overall survival (OS) and disease-free survival (DFS) rates of patients with a low DICER1 mRNA expression were significantly worse compared to patients with a high DICER1 mRNA expression (OS P<0.001; DFS $\mathrm{P}<0.001)$. In the Cox multivariate analysis, DICER1 mRNA expression in CRC tissues was identified as an independent prognostic factor for OS [hazard ratio (HR), $0.30 ; 95 \%$ confidence interval $(\mathrm{CI}), 0.13-0.64 ; \mathrm{P}=0.001]$ and DFS (HR, 0.23; 95\% CI, 0.10-0.48; $\mathrm{P}=0.001$ ). This study
\end{abstract}

Correspondence to: Takuya Akahane, Department of Surgery, Teikyo University School of Medicine, 2-11-1 Kaga, Itabashi-ku, Tokyo 173-0003, Japan

E-mail: iinuma@med.teikyo-u.ac.jp

Key words: DICER1, colorectal cancer, overall survival, progression-free survival demonstrated that a reduced DICER1 mRNA expression is associated with poor prognosis in CRC patients.

\section{Introduction}

Colorectal cancer (CRC) is the third most common cause of cancer mortality worldwide (1). Despite the fact that recent advances in chemotherapeutic regimens and combination with radiotherapy have improved survival of advanced-stage CRC patients, an increased risk of recurrence and metastasis, and thus high mortality rates, are associated with advanced-stages of the disease (2). Therefore, identification of novel prognostic biomarkers to improve patient outcome and to assess individual prognosis is required.

MicroRNAs (miRNAs) are a class of small, mature non-coding 21-25 nucleotides that participate in the regulation of cell differentiation, cell cycle progression and apoptosis (3-5). miRNAs target protein-coding mRNAs at the post-transcriptional level by direct cleavage of the mRNA or by inhibition of protein synthesis (6). It has been hypothesized that miRNAs are highly involved in cancer development (4). The synthesis and maturation of miRNAs requires a set of proteins known collectively as miRNA-processing machinery (7). miRNAs are transcribed by polymerase II as long primary transcripts (pri-miRNAs). Pri-miRNAs are spliced in the nuceleus by the enzyme Drosha to form 70-100 nucleotide hairpin precursors of miRNA (pre-miRNA) (8). The pre-miRNAs are exported to the cytoplasm by Exportin-5, where they are further processed by the RNAse III endonuclease enzyme DICER 1, resulting in short double-stranded miRNA (miRNA douplex) of 19-24 nucleotides $(9,10)$.

Cytoplasmic ribonuclease type III DICER1 is a key enzyme involved in the miRNA processing pathway that regulates RNA-based gene silencing by the cleavage of miRNA precursor (11-16). Mounting evidence suggests that DICER1 expression levels are associated with clinical outcomes in lung, ovarian, breast and prostate cancers (17-21). Therefore, it is of interest to determine whether or not DICER1 may be used as a prognostic marker to predict an individual patient's risk. Using the immunohistochemical method (IHC), only a few clinical studies have investigated the usefulness of DICER1 protein levels as a prognostic factor in CRC patients $(22,23)$. However, the prognostic values of DICER1 protein levels in these studies 
were contradictory. Furthermore, the prognostic significance of DICER1 mRNA level in CRC patients has yet to be elucidated.

In this study, we investigated the association between the clinicopathological characteristics and prognostic value of DICER1 mRNA in 260 CRC patients.

\section{Patients and methods}

Patients and tissue samples. A total of 260 CRC patients were studied between September, 2000 and Apri 1, 2006 at the Teikyo University Hospital (Tokyo, Japan). The median follow-up period was 45 months (range, 24-70). The samples were obtained from patients who did not receive any chemotherapy or radiotherapy prior to surgery. Immediately following surgical resection, primary CRC and normal adjacent tumor tissues (normal tissue) were mounted using Tissue-Tek O.C.T Compound (Sakura Finetechnical Co., Ltd., Tokyo, Japan) and frozen in liquid nitrogen. The tissues were then stored at $-80^{\circ} \mathrm{C}$ until laser-capture micro-dissection (LCM). The study protocol conformed to the guidelines of the ethics committee, and was approved by the review board of the Teikyo University, while written informed consent was obtained from the patients.

Follow-up of patients. Post-operative follow-up was performed along the guidelines published by the Japanese Society for Cancer of the Colon and Rectum. Confirmation of recurrence in the patients was required to evaluate imaging or pathological diagnosis. Physical examination and tumor marker (CEA and CA19-9) testing was conducted every 3 months for 3 years and then every 6 months for 5 years. Computed tomography (CT) or magnetic resonance imaging (MRI) scans were repeated every 3 months for 3 years and then every 6 months for up to 5 years, following surgery. Colon evaluation, including colonoscopy or colon radiography was performed every 2 years or annually for 3 years.

LCM and RNA isolation. Frozen sections (10 $\mu \mathrm{m})$ of CRC and normal tissues were prepared using a Leica CM 1900 cryostat (Leica, Wetzlar, Germany) at $-25^{\circ} \mathrm{C}$. The sections were placed on membrane-coated glass slides (Leica), fixed in $75 \%$ alcohol for $30 \mathrm{sec}$ and stained with $0.5 \%$ violet-free methyl green (Sigma-Aldrich, St. Louis, MO, USA). After staining, the sections were air-dried and micro-dissected using a Leica AS LMD system (Leica). LCM caps were stored at $-80^{\circ} \mathrm{C}$ until RNA isolation.

Total RNAs were extracted using a miRNeasy Mini Kit (Qiagen, Inc., Valencia, CA, USA) and were treated with DNase I, according to the manufacturer's instructions (Qiagen). Total RNA was reverse-transcribed to complementary DNA (cDNA), using the SuperScript II reverse transcriptase system with random hexamer primers, according to the manufacturer's instructions (Invitrogen Corporation, Carlsbad, CA, USA).

Quantitative real-time reverse transcription polymerase chain reaction (RT-PCR) for DICERI $m R N A$. The relative expression levels of DICER1 and GAPDH mRNA (internal control) were determined by quantitative real-time PCR amplification (qRT-PCR) using a LightCycler 480 (Roche Diagnostics Corp., Indianapolis, IN, USA). The amplifications of these genes were performed using the LightCycler

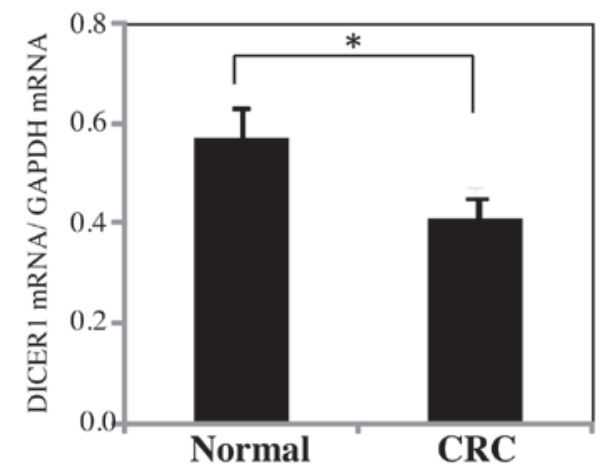

Figure 1. Comparison of DICER1 mRNA levels between colorectal cancer (CRC) and normal tissues. Primary CRC and normal adjacent tumor tissues (normal tissues) were obtained from 260 CRC patients. DICER1 mRNA levels were detected using TaqMan PCR assay and normalized to GAPDH mRNA. Data are shown as the mean \pm standard error. ${ }^{*} \mathrm{P}=0.039$.

480 Probe Master (Roche Diagnostics Corp.) and TaqMan Gene Expression Assays for DICER1 (Hs00229023_m1) and GAPDH (Hs02758991_g1) (Applied Biosystems, Inc., Carlsbad, CA, USA). The PCR conditions of these genes are $95^{\circ} \mathrm{C}$ for $5 \mathrm{~min}$, followed by 40 cycles $95^{\circ} \mathrm{C}$ for $1 \mathrm{sec}, 60^{\circ} \mathrm{C}$ for $20 \mathrm{sec}$. All the samples were performed in triplicates. The expression levels of DICER1 mRNA were normalized to GAPDH mRNA expression.

Statistical analysis. Data were shown as the mean \pm standard error. The correlations were analyzed using the Student's t-test, the Chi-square test and analysis of variance (ANOVA). The cut-off value of DICER1 mRNA was determined by receiver operating characteristic (ROC) curves, which used the JMP 9.0 software (SAS Inst. Inc., Cary, NC, USA). Overall survival (OS) and disease-free survival (DFS) curves were analyzed using the Kaplan-Meier method and the differences were examined using log-rank tests. Cox proportional-hazards regression analysis was used to estimate univariate and multivariate hazard ratios for OS and DFS. P values were two-sided, and $\mathrm{P}<0.05$ was considered to indicate a statistically significant difference. Statistical analyses were performed using the JMP 9.0 software (SAS Inst. Inc.).

\section{Results}

Expression of DICERI $\mathrm{mRNA}$ in CRC and normal tissues. A comparison of DICER $1 \mathrm{mRNA}$ expression levels of the primary $\mathrm{CRC}$ and normal adjacent tumor tissues (normal tissues) were compared (Fig. 1). The samples were collected from 260 CRC patients. DICER1 mRNA levels were normalized by GAPDH mRNA levels. In this study, DICER1 mRNA levels of CRC tissues showed a significant decrease as compared to normal tissues $(\mathrm{P}=0.039)$.

Correlation between the expression of clinicopathological factors and DICER $1 \mathrm{mRNA}$ in tumor tissues. This study comprised 260 CRC patients (153 men and 107 women), with a mean age of 67 years (range, 27-88). To evaluate the correlation between the DICER1 mRNA levels and the clinicopathological characteristics, patients were divided 
Table I. Clinicopathological data and DICER1 mRNA expression in 260 CRC patients.

\begin{tabular}{|c|c|c|c|c|}
\hline \multirow[b]{2}{*}{ Variables } & \multirow[b]{2}{*}{ Total no. of patients } & \multicolumn{2}{|c|}{ DICER 1 mRNA expression, no. of patients (\%) } & \multirow[b]{2}{*}{ P-value } \\
\hline & & High & Low & \\
\hline Gender & & & & 0.909 \\
\hline Male & 153 & $64(41.83)$ & $89(58.17)$ & \\
\hline Female & 107 & $44(41.12)$ & $63(58.88)$ & \\
\hline Tumor size (cm) & & & & $0.001^{\mathrm{a}}$ \\
\hline$<5$ & 147 & $74(50.34)$ & $73(49.66)$ & \\
\hline$\geq 5$ & 113 & $34(30.09)$ & $79(69.91)$ & \\
\hline Depth of invasion & & & & $0.002^{\mathrm{a}}$ \\
\hline$\leq \mathrm{pT} 2$ & 24 & $17(70.83)$ & $7(29.17)$ & \\
\hline$\geq \mathrm{pT} 3$ & 236 & $91(38.56)$ & $145(61.44)$ & \\
\hline Localization & & & & 0.860 \\
\hline Colon & 150 & $63(42.00)$ & $87(58.00)$ & \\
\hline Rectum & 110 & $45(40.91)$ & $65(59.09)$ & \\
\hline Histological type & & & & 0.319 \\
\hline Well & 174 & $76(43.68)$ & $98(56.32)$ & \\
\hline Unwell & 86 & $32(37.21)$ & $54(62.79)$ & \\
\hline Lymph node metastasis & & & & $0.008^{\mathrm{a}}$ \\
\hline Negative & 124 & $62(50.00)$ & $62(50.00)$ & \\
\hline Positive & 136 & $46(33.82)$ & $90(66.18)$ & \\
\hline Lymphatic invasion & & & & $0.014^{\mathrm{a}}$ \\
\hline Negative & 150 & $72(48.00)$ & $78(52.00)$ & \\
\hline Positive & 110 & $36(32.73)$ & $74(67.27)$ & \\
\hline Venous invasion & & & & 0.804 \\
\hline Negative & 106 & $45(42.45)$ & $61(57.55)$ & \\
\hline Positive & 154 & $63(40.91)$ & $91(59.09)$ & \\
\hline Liver metastasis & & & & 0.178 \\
\hline Negative & 222 & $96(43.24)$ & $126(56.76)$ & \\
\hline Positive & 38 & $12(31.58)$ & $26(68.42)$ & \\
\hline Peritoneum dissemination & & & & 0.116 \\
\hline Negative & 243 & $104(42.80)$ & $139(57.20)$ & \\
\hline Positive & 17 & $4(23.53)$ & $13(76.47)$ & \\
\hline Dukes' stage & & & & $0.015^{\mathrm{a}}$ \\
\hline A & 40 & $25(62.50)$ & $15(37.50)$ & \\
\hline B & 68 & $30(44.12)$ & $38(55.88)$ & \\
\hline $\mathrm{C}$ & 88 & $32(36.36)$ & $56(63.64)$ & \\
\hline $\mathrm{D}$ & 64 & $21(32.81)$ & 43 (67.19) & \\
\hline
\end{tabular}

${ }^{\mathrm{a}} \mathrm{P}=0.039 . \mathrm{CRC}$, colorectal cancer.

into the high- and low-level groups. The cut-off level for DICER 1 mRNA was set at 0.275 based on analysis of the ROC curve. As shown in Table I, a statistically significant association was observed between DICER1 mRNA expression and tumor size, depth of invasion, lymph node metastasis, lymphatic invasion and Dukes' stage.

Correlation between DICERI mRNA levels and OS and $D F S$. The prognostic significances of DICER1 mRNA levels was evaluated for the OS in all 260 patients and DFS in the 196 patients who underwent curative surgery. The average follow-up period for OS was 39.4 \pm 25.8 months and that of DFS was $38.8 \pm 21.5$ months. In each analysis, patients were divided into the high and low DICER1 mRNA expression groups, as described above.

Fig. 2 shows the Kaplan-Meier OS curve of the CRC patients based on the status of DICER1 mRNA levels. The OS of patients in the low DICER1 group showed significantly 
Table II. Univariate and multivariate analysis of prognostic factors for OS.

\begin{tabular}{|c|c|c|c|c|c|c|}
\hline \multirow[b]{2}{*}{ Variables } & \multicolumn{3}{|c|}{ Univariate analysis } & \multicolumn{3}{|c|}{ Multivariate analysis } \\
\hline & $\begin{array}{l}\text { Regression } \\
\text { coefficient }\end{array}$ & $\begin{array}{c}\text { Hazard ratio } \\
(95 \% \mathrm{CI})\end{array}$ & $\mathrm{P}$-value & $\begin{array}{c}\text { Regression } \\
\text { coefficient }\end{array}$ & $\begin{array}{c}\text { Hazard ratio } \\
(95 \% \mathrm{CI})\end{array}$ & P-value \\
\hline Tumor size & 0.65 & $\begin{array}{c}1.92 \\
(1.22-3.04)\end{array}$ & $0.005^{\mathrm{a}}$ & -0.23 & $\begin{array}{c}0.79 \\
(0.43-1.47)\end{array}$ & 0.467 \\
\hline $\begin{array}{l}\text { Depth of } \\
\text { invasion }\end{array}$ & 2.23 & $\begin{array}{c}9.34 \\
(2.07-164.75)\end{array}$ & $0.008^{\mathrm{a}}$ & 0.13 & $\begin{array}{c}1.10 \\
(0.19-20.85)\end{array}$ & 0.907 \\
\hline $\begin{array}{l}\text { Lymph node } \\
\text { metastasis }\end{array}$ & 1.25 & $\begin{array}{c}3.50 \\
(2.12-6.05)\end{array}$ & $<0.001^{\mathrm{a}}$ & 0.03 & $\begin{array}{c}1.03 \\
(0.51-2.13)\end{array}$ & 0.945 \\
\hline $\begin{array}{l}\text { Lymphatic } \\
\text { invasion }\end{array}$ & 0.99 & $\begin{array}{c}2.70 \\
(1.71-4.33)\end{array}$ & $<0.001^{\mathrm{a}}$ & 0.13 & $\begin{array}{c}1.14 \\
(0.61-2.16)\end{array}$ & 0.683 \\
\hline Venous invasion & 1.00 & $\begin{array}{c}2.71 \\
(1.64-4.69)\end{array}$ & $<0.001^{\mathrm{a}}$ & 0.27 & $\begin{array}{c}1.31 \\
(0.66-2.76)\end{array}$ & 0.444 \\
\hline Histological type & 0.65 & $\begin{array}{c}1.92 \\
(1.22-3.04)\end{array}$ & $0.005^{\mathrm{a}}$ & 0.52 & $\begin{array}{c}1.67 \\
(0.89-3.15)\end{array}$ & 0.108 \\
\hline Liver metastasis & 1.61 & $\begin{array}{c}4.98 \\
(2.94-8.23)\end{array}$ & $<0.001^{\mathrm{a}}$ & -0.23 & $\begin{array}{c}0.79 \\
(0.31-1.96)\end{array}$ & 0.618 \\
\hline $\begin{array}{l}\text { Peritoneum } \\
\text { dissemination }\end{array}$ & 1.94 & $\begin{array}{c}6.95 \\
(3.60-12.46)\end{array}$ & $<0.001^{\mathrm{a}}$ & 0.11 & $\begin{array}{c}1.11 \\
(0.38-3.03)\end{array}$ & 0.840 \\
\hline Serum CEA & 1.17 & $\begin{array}{c}3.23 \\
(1.93-5.60)\end{array}$ & $<0.001^{\mathrm{a}}$ & 0.15 & $\begin{array}{c}1.16 \\
(0.57-2.39)\end{array}$ & 0.686 \\
\hline Serum CA19-9 & 0.63 & $\begin{array}{c}1.87 \\
(1.07-3.20)\end{array}$ & $0.027^{\mathrm{a}}$ & 0.07 & $\begin{array}{c}1.07 \\
(0.52-2.14)\end{array}$ & 0.855 \\
\hline Dukes' stage & 1.47 & $\begin{array}{c}4.33 \\
(3.11-6.21)\end{array}$ & $<0.001^{\mathrm{a}}$ & 1.18 & $\begin{array}{c}3.27 \\
(1.75-6.22)\end{array}$ & $0.001^{\mathrm{a}}$ \\
\hline DICER1 mRNA & -1.93 & $\begin{array}{c}0.15 \\
(0.02-0.46)\end{array}$ & $0.002^{\mathrm{a}}$ & -1.19 & $\begin{array}{c}0.30 \\
(0.13-0.64)\end{array}$ & $0.001^{\mathrm{a}}$ \\
\hline
\end{tabular}

${ }^{\mathrm{a}} \mathrm{P}=0.039$. OS, overall survival; $\mathrm{CI}$, confidence interval.

worse survival rates as compared to the high DICER1 group $(\mathrm{P}<0.001)$. Fig. 3 shows the Kaplan-Meier DFS curves of the CRC patients, based on the status of DICER1 mRNA levels. The DFS of patients in the low DICER1 group also showed significantly worse survival rates as compared to the high DICER1 group $(\mathrm{P}<0.001)$. These findings suggest that a low expression of DICER1 mRNA is associated with worse OS and DFS in CRC patients.

Univariate and multivariate Cox analyses for OS. Table II shows the results of the univariate and multivariate Cox proportional hazard regression analyses for OS in the CRC patients. Multivariate analysis was performed for factors exhibiting statistical significance in the univariate analysis. In the univariate analysis, tumor size, depth of invasion, lymph node metastasis, lymphatic invasion, venous invasion, histological type, liver metastasis, peritoneal dissemination, serum CEA, serum CA19-9, Dukes' stage and DICER1 mRNA level, while in the multivariate analysis, Dukes' stage and DICER1 mRNA showed statistical significance for OS. Table III shows the results of univariate and multivariate
Cox analyses for DFS in CRC patients who underwent curative surgery $(n=196)$. In the univariate analysis, depth of invasion, venous invasion, serum CEA, Dukes' stage and DICER1 mRNA, while in the multivariate analysis, venous invasion, Dukes' stage and DICER1 mRNA showed statistical significance for DFS.

These results suggest that DICER1 mRNA levels of tumor tissues have an independent prognostic value for OS and DFS in CRC patients.

\section{Discussion}

In the present study, we aimed to examine the association of clinicopathological variables and the prognostic value of DICER1 mRNA in 260 CRC patients. Our findings demonstrate that the expression of DICER1 mRNA of CRC tissues showed a significant correlation between the tumor size, depth of invasion, lymph node metastasis, lymphatic invasion and Dukes' stage. Furthermore, the low expression of DICER1 mRNA in CRC tissue showed a markedly poor prognosis for OS and DFS in CRC patients. 
Table III. Univariate and multivariate analysis of prognostic factors for DFS.

\begin{tabular}{|c|c|c|c|c|c|c|}
\hline \multirow[b]{2}{*}{ Variables } & \multicolumn{3}{|c|}{ Univariate analysis } & \multicolumn{3}{|c|}{ Multivariate analysis } \\
\hline & $\begin{array}{l}\text { Regression } \\
\text { coefficient }\end{array}$ & $\begin{array}{l}\text { Hazard ratio } \\
(95 \% \mathrm{CI})\end{array}$ & P-value & $\begin{array}{l}\text { Regression } \\
\text { coefficient }\end{array}$ & $\begin{array}{l}\text { Hazard ratio } \\
(95 \% \mathrm{CI})\end{array}$ & P-value \\
\hline Tumor size & 0.27 & $\begin{array}{c}1.31 \\
(1.31-2.31)\end{array}$ & 0.369 & & - & \\
\hline $\begin{array}{l}\text { Depth of } \\
\text { invasion }\end{array}$ & 1.26 & $\begin{array}{c}3.51 \\
(1.09-6.48)\end{array}$ & $0.034^{\mathrm{a}}$ & -0.44 & $\begin{array}{c}0.66 \\
(0.16-4.39)\end{array}$ & 0.604 \\
\hline $\begin{array}{l}\text { Lymphatic } \\
\text { invasion }\end{array}$ & 0.52 & $\begin{array}{c}1.69 \\
(0.94-2.97)\end{array}$ & 0.077 & & - & \\
\hline Venous invasion & 0.70 & $\begin{array}{c}2.00 \\
(1.13-3.67)\end{array}$ & $0.018^{\mathrm{a}}$ & 0.54 & $\begin{array}{c}1.73 \\
(0.95-3.21)\end{array}$ & 0072 \\
\hline Histological type & 0.40 & $\begin{array}{c}1.49 \\
(0.81-2.66)\end{array}$ & 0.195 & & - & \\
\hline Serum CEA & 0.63 & $\begin{array}{c}1.87 \\
(1.05-3.30)\end{array}$ & $0.035^{\mathrm{a}}$ & 0.39 & $\begin{array}{c}1.48 \\
(0.82-2.62)\end{array}$ & 0.189 \\
\hline Serum CA19-9 & 0.60 & $\begin{array}{c}1.82 \\
(0.91-3.46)\end{array}$ & 0.089 & & - & \\
\hline Dukes' stage & 0.87 & $\begin{array}{c}2.39 \\
(1.54-3.91)\end{array}$ & $<0.001^{\mathrm{a}}$ & 0.73 & $\begin{array}{c}2.07 \\
(1.28-3.53)\end{array}$ & $0.003^{\mathrm{a}}$ \\
\hline DICER1 mRNA & -1.54 & $\begin{array}{c}0.21 \\
(0.09-0.43)\end{array}$ & $<0.001^{\mathrm{a}}$ & -1.46 & $\begin{array}{c}0.23 \\
(0.10-0.48)\end{array}$ & $0.001^{\mathrm{a}}$ \\
\hline
\end{tabular}

${ }^{\mathrm{a}} \mathrm{P}=0.039$. DFS, disease-free survival; CI, confidence interval.

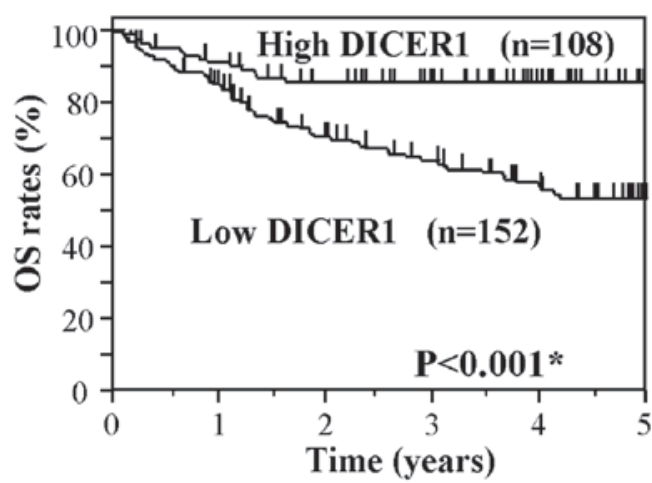

Figure 2. Overall survival (OS) curves based on DICER1 mRNA expression. The OS for 260 CRC patients was analyzed using the Kaplan-Meier survival curve. CRC patients were divided into the low and high DICER1mRNA group. The OS of patients in the low-DICER1 mRNA groups showed markedly worse survival rates as compared to the high-DICER1 mRNA group. Log-rank test, $\mathrm{P}<0.001$.

DICER1 is a key enzyme responsible for the cleavage of miRNA precursors that is necessary for the production of mature miRNAs (11-16). DICER1 is capable of splicing the hairpin-like structure RNA and double-stranded RNA into mature miRNA or siRNA. MiRNAs are highly involved in several developmental and biological cell processes including timing of cell development, haematopoiesis, organogenesis, apoptosis, cell differentiation and proliferation $(12,25)$.

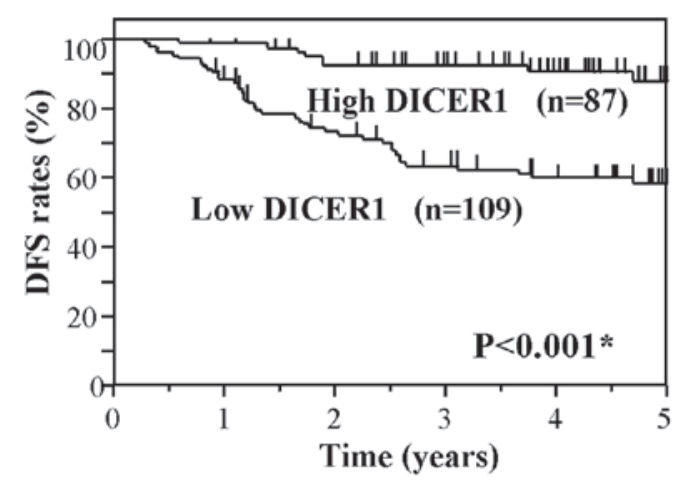

Figure 3. Disease-free survival (DFS) curves based on DICER1 mRNA expression. The DFS for 196 CRC patients who underwent curative surgery was analyzed using the Kaplan-Meier survival curve. CRC patients were divided into the low and high-DICER1 mRNA groups. The DFS of patients in the low-DICER1 mRNA group showed markedly worse survival rates as compared to the high-DICER1 mRNA group. Log-rank test, $\mathrm{P}<0.001$.

Involvement of miRNA-base regulatory mechanisms is important in several diseases, including cancer (25-27). A general deregulation of miRNAs has been described as a key feature of several cancer types. Therefore, alternation of DICER1 expression may affect the development and progression of cancer via the loss of miRNA-mediated gene regulation.

DICER1 expression in cancer and normal tissues has shown inconsistent results in various cancer types. In this 
study, DICER1 mRNA levels of CRC showed a significant decrease compared to normal tissues. Similar to our findings, a decreased DICER1 expression has been shown in CRC, lung, gastric and ovarian cancers $(17,20,28,29)$. In their study, Papachristou et al (30) reported that the mRNA levels of DICER did not exhibit significant differences in normal and CRC tissues. Conversely, the overexpression of DICER1 has been reported in prostate adenocarcinoma, ovarian cancer and acute myeloid leukemia $(19,31,32)$. The correlation between the DICER1 levels in CRC tissues and their clinicopathological factors are also noteworthy. We have demonstrated significant correlations between the DICER1 mRNA and tumor size, depth of invasion, lymph node metastasis, lymphatic invasion and Dukes' stage. Using the IHC method, Faggad et al (23) reported that the DICER1 protein expression in CRC tissues showed a significant correlation with tumor grade, lymph node metastasis, localization of tumor and tumor stage, thereby partially supporting our findings.

We also evaluated the prognostic value of DICER1 mRNA in CRC tissues. The effect of expression on prognosis has been studied in several cancers with controversial outcomes in various cancer types. In patients with ovarian, lung and breast cancers, decreased DICER1 levels in the tumor tissues showed a poor prognosis $(17,18,21)$. Similarly, in patients with myeloma, nasopharyngeal carcinoma and chronic lymphocytic leukemia, decreased DICER1 levels were also a marker of poor prognosis (33-35). Conversely, the overexpression of DICER1 expression has been reported as a prognostic factor in prostate adenocarcinoma (19). Regarding CRC, the results of prognostic values of DICER1 in tumor tissues are also controversial.

Recently, Faber et al (24) reported that the overexpression of DICER1 predicts poor survival in CRC patients with pT2 or pT3 stages and without metastatic disease ( $\mathrm{pN} 0$ and $\mathrm{pM} 0$ ). By contrast, Faggad et al (23) reported that the downregulation of DICER1 is a prognostic factor in CRC patients with WHO stage I, II, III and IV. These studies examined the DICER1 protein levels of tissue microarrays (TMA) using IHC staining. In this study, we selected the DICER1 mRNA detection using the Taqman RT-PCR method, with the aim of obtaining high sensitivity and objective analysis, since a small sample size of TMA may limit the value of TMA due to tumor heterogeneity.

Furthermore, Grelier et al (21) compared the prognostic value of DICER1 of breast cancer in the two measuring methods: real time RT-PCR and IHC. They reported that DICER1 mRNA levels were predictive for metastatic-free survival. However, the protein expression was not informative for survival. Of note, our data showed that low expression levels of DICER1 mRNA in CRC tissues significantly correlate with poorer OS and DFS, thereby supporting the findings of Faggad et al (36). The expression level of DICER1 directly influences the biosynthesis of miRNA. In ovarian cancer, a link between reduced DICER1 expression and a global downregulation of miRNA are reported.

The aggressive tumors are thought to have decreased total microRNA levels, contributing to their poor differentiation. The downregulation of miRNA may have an impact on the development of tumor cells leading to poor prognosis of patients. However, the reason for the discrepancy with the survival results reported by Faber et al (24) is to be studied in future large-scale studies of each CRC stage. To the best of our knowledge, this is the first study to demonstrate the independent prognostic value of a decreased expression of DICER1 mRNA in CRC.

In conclusion, our study has demonstrated that reduced DICER1 mRNA expression of tumor tissues shows a prognostic significance in CRC patients. Our finding of DICER1 mRNA expression being an independent marker capable of predicting high-risk patients is potentially useful in the individualized management and monitoring of CRC patients. In the future, these molecules may serve as a novel target with beneficial therapeutic applications.

\section{Acknowledgements}

The author thanks Professor Y. Hashiguchi and Dr Iinuma for their helpful suggestions, as well as Dr K. Matsuda, Miss J. Tamura and all members of the colorectal group for their help. This study was supported by the JSPS KAKENHI, grant no. 24591984.

\section{References}

1. Gill S, Thomas RR and Goldberg RM: Review article: colorectal cancer chemotherapy. Aliment Pharmacol Ther 18: 683-692, 2003.

2. Aggarwal S and Chu E: Current therapies for advanced colorectal cancer. Oncology 19: 589-595, 2005.

3. Caldas C and Brenton JD: Sizing up miRNAs as cancer genes. Nat Med 11: 712-714, 2005.

4. Esquela-Kerscher A and Slack FJ : Oncomirs-microRNAs with a role in cancer. Nat Rev Cancer 6: 259-269, 2006.

5. Jovanovic M and Hengartner MO: miRNAs and apoptosis: RNAs to die for. Oncogene 25: 6176-6187, 2006.

6. Mott JL: MicroRNAs involved in tumor suppressor and oncogene pathways: implications for hepatobiliary neoplasia. Hepatology 50: 630-637, 2009.

7. Lee Y, Kim M, Han J, Yeom KH, Lee S, Baek SH and Kim VN: MicroRNA genes are transcribed by RNA polymerase II. EMBO J 23: 4051-4060, 2004.

8. Lee Y, Ahn C, Han J, et al: The nuclear RNase III Drosha initiates microRNA processing. Nature 6956: 415-419, 2003.

9. Lund E, Güttinger S, Calado A, Dahlberg JE and Kutay U: Nuclear export of microRNA precursors. Science 5654: 95-98, 2004.

10. Yi R, Qin Y, Macara IG and Cullen BR: Exportin-5 mediates the nuclear export of pre-microRNAs and short hairpin RNAs. Genes Dev 17: 3011-3016, 2003.

11. Hutvágner G, McLachlan J, Pasquinelli AE, Bálint E, Tuschl T and Zamore PD: A cellular function for the RNA-interference enzyme Dicer in the maturation of the let-7 small temporal RNA. Science 5531: 834-838, 2001.

12. Bartel DP: MicroRNAs: genomics, biogenesis, mechanism, and function. Cell 116: 281-297, 2004.

13. Cullen BR: Transcription and processing of human microRNA precursors. Mol Cell 16: 861-865, 2004.

14. Carmell MA and Hannon GJ: RNase III enzymes and the initiation of gene silencing. Nat Struct Mol Biol 11: 214-218, 2004.

15. Cummins JM, He Y, Leary RJ, et al: The colorectal microRNAome. Proc Natl Acad Sci USA 103: 3687-3692, 2006.

16. Ambros V, Bartel B, Bartel DP, et al: A uniform system for microRNA annotation. RNA 9: 277-279, 2003.

17. Karube Y, Tanaka H, Osada H, et al: Reduced expression of Dicer associated with poor prognosis in lung cancer patients. Cancer Sci 96: 111-115, 2005.

18. Merritt WM, Lin YG, Han LY, et al: Dicer, Drosha, and outcomes in patients with ovarian cancer. N Engl J Med 359: 2641-2650, 2008.

19. Chiosea S, Jelezcova E, Chandran U, Acquafondata M, McHale T, Sobol RW and Dhir R: Up-regulation of dicer, a component of the MicroRNA machinery, in prostate adenocarcinoma. Am J Pathol 169: 1812-1820, 2006. 
20. Chiosea S, Jelezcova E, Chandran U, Luo J, Mantha G, Sobol RW and Dacic S: Overexpression of Dicer in precursor lesions of lung adenocarcinoma. Cancer Res 67: 2345-2350, 2007.

21. Grelier G, Voirin N, Ay AS, et al: Prognostic value of Dicer expression in human breast cancers and association with the mesenchymal phenotype. Br J Cancer 101: 673-683, 2009.

22. Stratmann J, Wang CJ, Gnosa S, Wallin A, Hinselwood D, Sun XF and Zhang H: Dicer and miRNA in relation to clinicopathological variables in colorectal cancer patients. BMC Cancer 11: 345, 2011

23. Faggad A, Kasajima A, Weichert W, Stenzinger A, Elwali NE, Dietel $M$ and Denkert C: Down-regulation of the microRNA processing enzyme Dicer is a prognostic factor in human colorectal cancer. Histopathology 20: doi: 10.1111/j.1365-2559. 2011.04110.x, 2012.

24. Faber C, Horst D, Hlubek F and Kirchner T: Overexpression of Dicer predicts poor survival in colorectal cancer. Eur J Cancer 47: 1414-1419, 2011

25. Wiemer EA: The role of microRNAs in caner: no small matter. Eur J Cancer 43: 1529-1544, 2007.

26. Nelson P, Kiriakidou M, Sharma A, Maniataki E and Mourelatos Z: The microRNA world: small is mighty. Trends Biochem Sci 28: 534-540, 2003.

27. Calin GA and Croce CM: MicroRNA-cancer connection: the beginning of a new tale. Cancer Res 66: 7390-7394, 2006

28. Zheng ZH, Sun XJ, Fu WN, Guan Y, Gao F, Wang Y and Sun KL: Decreased expression of DICER1 in gastric cancer. Chin Med J 120: 2099-2104, 2007
29. Pampalakis G, Diamandis EP, Katsaros D and Sotiropoulou G: Down-regulation of dicer expression in ovarian cancer tissues. Clin Biochem 43: 324-327, 2010.

30. Papachristou DJ, Korpetinou A, Giannopoulou E, et al: Expression of the ribonucleases Drosha, Dicer, and Ago2 in colorectal carcinomas. Virchows Arch 459: 431-440, 2011.

31. Flavin RJ, Smyth PC, Finn SP, et al: Altered eIF6 and Dicer expression is associated with clinicopathological features in ovarian serous carcinoma patients. Mod Pathol 21: 676-684, 2008.

32. Martin MG, Payton JE and Link DC: Dicer and outcomes in patients with acute myeloid leukemia (AML). Leuk. Res 33: e127, 2009.

33. Guo X, Liao Q, Chen P, et al: The microRNA-processing enzymes: Drosha and Dicer can predict prognosis of nasoparyngeal carcinoma. J Cancer Res Clin Oncol 138: 49-56, 2012.

34. Zhu DX, Fan L, Lu RN, et al: Downregulation Dicer expression predicts poor prognosis in chronic lymphocytic leukemia. Cancer Sci 103: 875-881, 2012.

35. Sarasquete M, Gutierrez NC, Misiewicz-Krzeminska I, et al: Upregulation of Dicer is more frequent in monoclonal gammopathies of undetermined significance than in multiple myeloma patients and is associated with longer survival in symptomatic myeloma patients. Haematologica 96: 468-471, 2011.

36. Faggad A, Budczites J, Tchemitsa O, et al: Prognostic significance of Dicer expression in ovarian cancer-link to global microRNA changes and oestrogen receptor expression. J Pathol 220: 382-391, 2010. 